\title{
Productive Potential of Precious Wood Species in the State of Chiapas, Mexico
}

\author{
Genovevo Ramírez-Jaramillo ${ }^{1}$ Mónica Guadalupe Lozano-Contreras ${ }^{2 *}$, Jorge H. Ramírez-Silva1 \\ ${ }^{1}$ Centro de Investigación Regional Sureste del Instituto Nacional de Investigaciones Forestales, Agrícolas y Pecuarias (INIFAP), \\ Mérida, Yucatán, México \\ ${ }^{2}$ Campo Experimental Mocochá del Instituto Nacional de Investigaciones Forestales, Agrícolas y Pecuarias (INIFAP), Mocochá, \\ Yucatán, México \\ Email: ${ }^{\star}$ lozano.monica@inifap.gob.mx
}

How to cite this paper: Ramírez-Jaramillo, G., Lozano-Contreras, M.G. and RamírezSilva, J.H. (2021) Productive Potential of Precious Wood Species in the State of Chiapas, Mexico. Open Access Library Journal, 8: e7299.

https://doi.org/10.4236/oalib.1107299

Received: March 10, 2021

Accepted: April 13, 2021

Published: April 16, 2021

Copyright $\odot 2021$ by author(s) and Open Access Library Inc.

This work is licensed under the Creative Commons Attribution International License (CC BY 4.0).

http://creativecommons.org/licenses/by/4.0/

\begin{abstract}
In order to promote forest plantations in Mexico, the federal government has implemented, since 1977, programs such as the Commercial Forest Plantations Development Program (PRODEPLAN) and in 2000 launched the Strategic Forest Program for Mexico 2025. In spite of these initiatives, nowadays there are new programs (The Sembrando Vida Program) recording a critical deforestation rate of 115 thousand hectares per year and a population decrease of forest species which are endemics for Mexico and Central America. The main focus of the Sembrando Vida Program is the rescue of four timber species, although red cedar (Cedrela odorata L) and mahogany (Swietenia macrophylla King) are the two main ones. Both species are being produced under nurseries conditions, for future commercial plantations, in the state of Chiapas Mexico but there is a lack of information about the best agroecological conditions to be planted. The objective of this work was to determine the productive potential areas for cedar and mahogany under rainfed conditions in the state of Chiapas. The Arc/View version 3.3 software, which is a Geographic Information System developed by the American company ESRI was used to process and analyze the information. The results indicate that under rainfed conditions there are 81,116 hectares of high potential for cedar and 91,939 for mahogany, and 428,465 hectares of medium potential for cedar and 629,000 for mahogany.
\end{abstract}

\section{Subject Areas}

Agricultural Engineering

\section{Keywords}

Commercial Plantations, Zonification, Red Cedar, Mahogany 


\section{Introduction}

Red cedar (Cedrela odorata L.) and mahogany (Swietenia macrophylla King) are two forest species considered precious and economically highly important for the timber industry [1] [2]. The use of both species is very varied. By instance, Mahogany is used extensively in the manufacture of furniture, in joinery, for door and window frames, as well as panels. Less is used in arts and crafts, coffins, turned items, musical instruments such as pianos, and in boat building [3].

Cedar is used for manufacturing luxury furniture's, boards, trunks, cabinets, turned articles, sheet metal, joinery and in the construction of boats [4] [5]; in rural areas it is used as firewood, and shade in pastures, coffee and cocoa plantations [6].

Due to their qualities, Cedar and Mahogany are timber forest species, very important for the industry in the tropical areas of Mexico, representing the income for many peasant families that depend economically on this activity [7]. However, the activity is causing indiscriminate deforestation [8]. In addition, the industry is not only affected by the natural low population density of the species but also by the cost of harvesting and extraction due to inaccessible terrains and changeable climate.

It's considered that commercial plantations can diminish the problem of jungle deforestation, allowing to restore the natural tree cover and in the long term be a profitable activity for the producers. It has been reported that wood yield production, in commercial plantations, can be significantly higher than under natural conditions [8]. Due to the foregoing, the reforestation programs must be properly planned, keeping in mind, as the first action, to know how suitable the environmental conditions are for future growing species [9].

By instance, the state of Chiapas in Mexico is characterized by having variable landscapes with different heights of reliefs and slopes, favoring the diversity of climates (temperature and precipitation) and types of soils (depth, texture) appropriate to grow traditional and potential crops [10]. Hot-humid and sub-humid, semi-warm and temperate climates predominate with precipitations ranging from 700 to $4000 \mathrm{~mm}$ per year. All those factors have induced the genesis and development of various types of soils such as Cambisol, Regosol, Vertisol, Leptosol, Phaeozem, among others [11]; all of them with different potentials to grow forest species.

Given the socio-economic importance of Cedar and Mahogany, it was considered important to do this work with the aim of locating and mapping the most suitable cultivation areas under rainfed conditions.

\section{Materials and Methods}

The study was carried out under cabinet conditions in the Southeast Research Center of the National Institute for Forest, Agriculture and Livestock Research in Merida Yucatan, Mexico. 


\subsection{Agroecological Requirements}

Climatic conditions are basic factor to induce optimal growing of crops and so is their spatial distribution in the world. The elements of climate are key factors that induce the success or failure of cultivated crops [12] [13] [14] [15].

Basic agroecological information of the state of Chiapas was reviewed in order to determine the potential areas for Cedrela odorata (L) and Swietenia macrophylla King under rainfed conditions. When all agroecological soil and climate variables interacted properly, in a specific area, the zone was classified as a high potential one whilst when variables interacted properly but with some limitations the area was classified as sub-optimal one. When all factors were not properly, at all, the areas were unsuitable for both forest trees.

The agroecological requirements of cedar and mahogany were determined by consulting the bibliography, databases and expert knowledge. In Table 1 are shown all agroecological variables such as: soil type (texture, depth, $\mathrm{pH}$, drainage), average annual temperature, altitudes and slopes, among others which were considered to regionalize the state into different potential production areas.

Table 1. Agroecological requeriments of Cedrela odorata (L) and Swietenia macrophylla King.

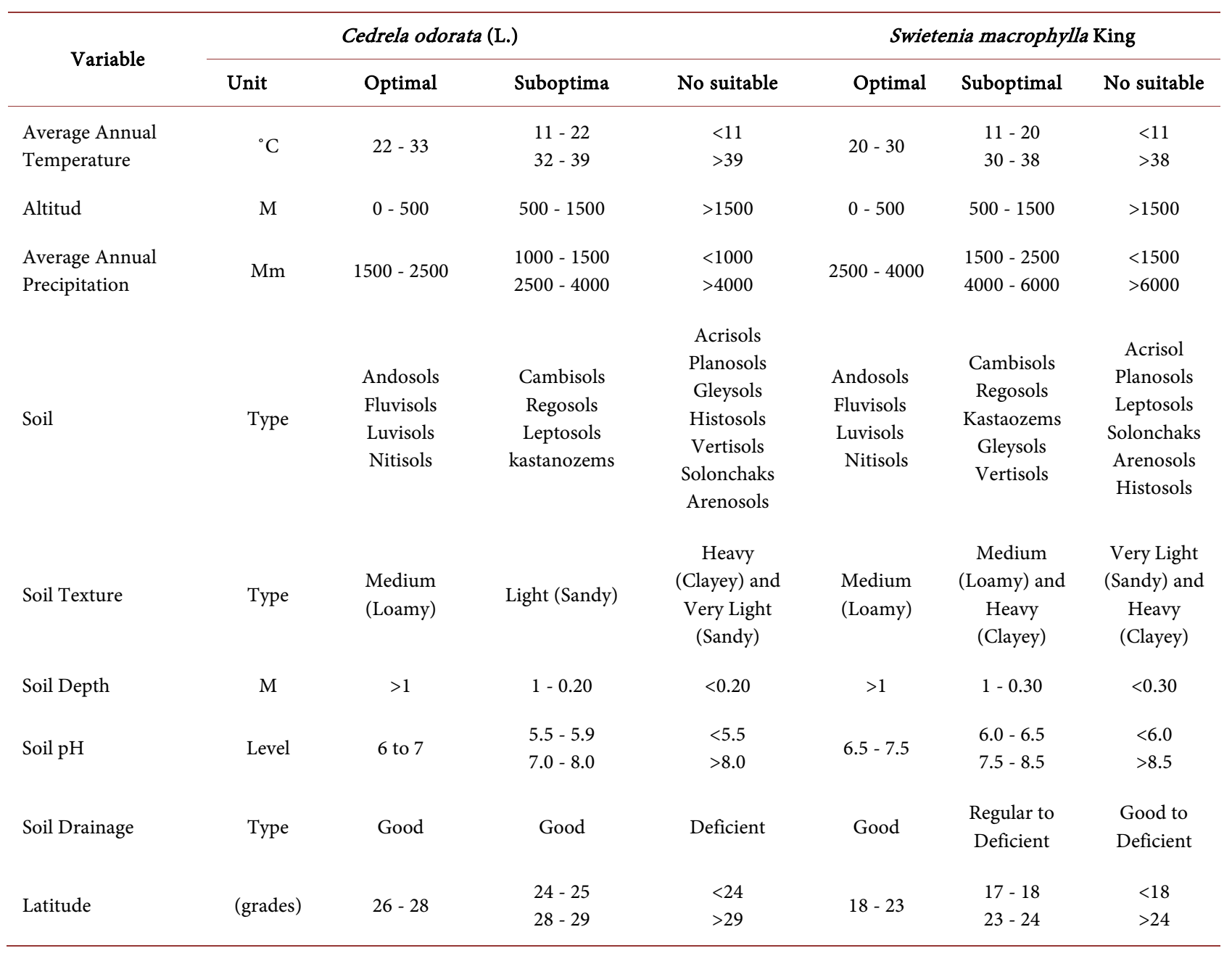




\subsection{Identification of Potential Areas for Cedrela odorata (L) and Swetania macrophyla King}

In order to process and analyze the information, Arc/View version 3.3 software was used. This is a program developed by the American company ESRI from which georeferenced data can be represented and the characteristics and distribution patterns of these data can be analyzed and eventually reported [16].

All activity in Arc/View occurs within the project, as a set of linked documents workable during the sessions. Projects can contain five types of documents such as: views, tables, charts, layouts (or printouts) and scripts. Windows can display names of all documents contained in Arc/View Project, organizing and storing the status of all of them; and the appearance of Windows can be easily modified.

The Project information is stored in a file ASCII format and always with extension *. apr. The Arc/View was used as a mainly vector map generator and the processing was performed in Arc/View 3.3 in order to carry out the intersection process of all variables with the purpose to generate areas of high and medium potential and unsuitable zones.

Vector maps are mainly generated through cartographic intersections between polygons, and potential classes are described and maintained at each intersection process. The final map provides information of all intercepted variables. These maps are more representative than the raster models because of their accuracy since the surface is estimated by polygonal processes (Figure 1).

Once the forest trees requirements were properly identified, the cartographic intersections were carried out to regionalize and locate the optimal and suboptimal areas for of Cedrela odorata (L) and Swietenia macrophylla King cultivation.

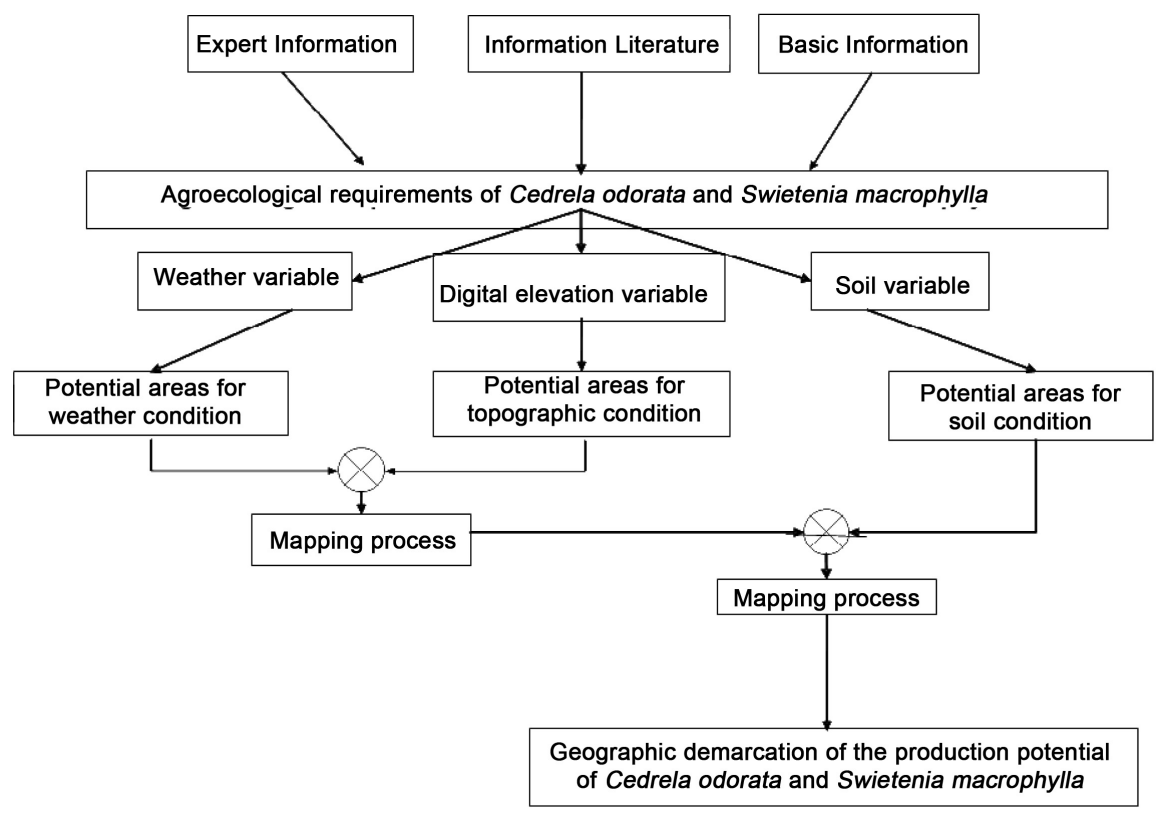

Figure 1. Methodological model used to determine the production potential. 


\section{Results and Discussion}

\subsection{Current and Potential Surface of Cedar and Mahogany}

The geographical distribution of cedar is scattered from the Atlantic to the Pacific ocean; on the Gulf of Mexico it is located in the south of Tamaulipas, southeast of San Luis Potosí, the region of the Huastecas, Veracruz, Tabasco and the Yucatan Peninsula; in the Pacific it is distributed from Sinaloa to Chiapas [17] [18]. While Mahogany is found in the states of Oaxaca, Veracruz, Tabasco and in the Yucatán Peninsula [19].

Currently, in the state of Chiapas it is reported the existence of more than 16 thousand hectares of Commercial Forest Plantations [20]. According to the results, it was determined that in rainfed areas, opened to cultivation, there are 428 thousand hectares of Medium Potential and 81 thousand hectares of High Potential suitable for cedar cultivation whilst for Mahogany there are 91 thousand hectares of High Potential and 629 thousand hectares of Medium Potential (Figure 2).

This surface far exceeds the current reported surface; and therefore, there is a great possibility to increase commercial plantations of Cedar and Mahogany in high and medium potential areas. This study also confirmed that as for Cedar there are 51 municipalities with high productive potential areas and 82 with medium potential as is shown in Figure 3. The same figure shows that for Mahogany there are 40 and 93 municipalities with high and medium potential areas respectively.

\subsection{Distribution of Potential Zones for Cedar}

Cedar (Cedrela odorata) is the second highly commercially valuable forest species after mahogany. Although the high and medium productive potential areas were determined to be in 51 and 82 municipalities respectively, the most outstanding ones, because of having the largest areas, are the next to be mentioned.

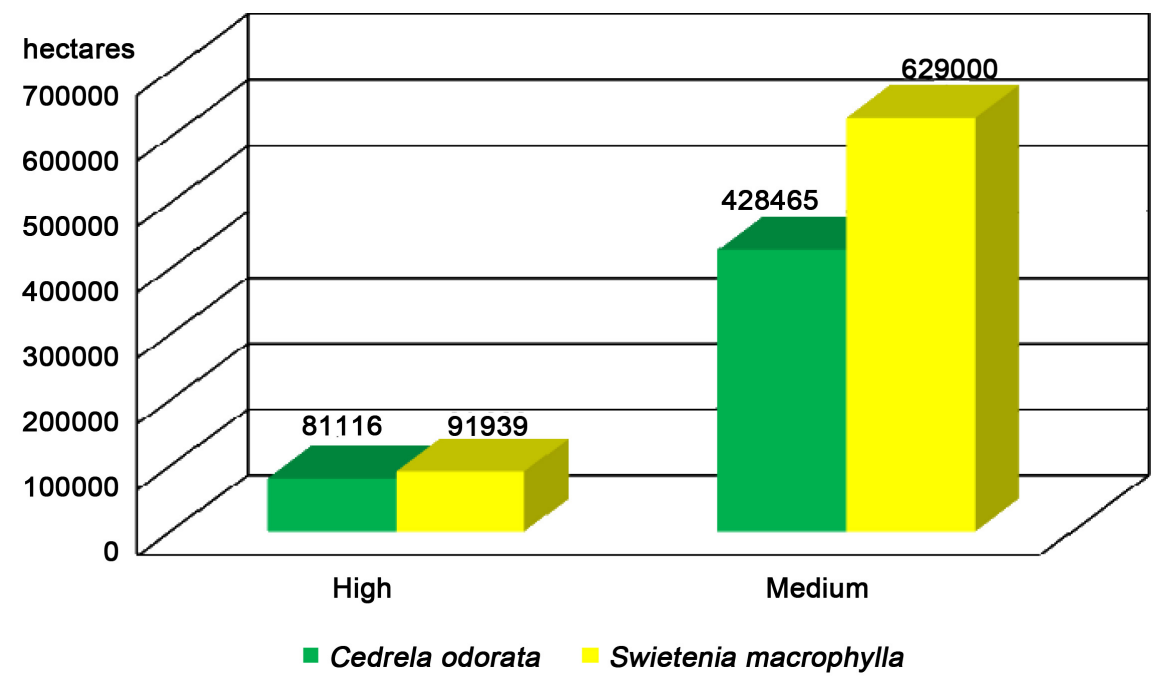

Figure 2. High and medium potential areas for cedar and mahogany in Chiapas, Mexico. 


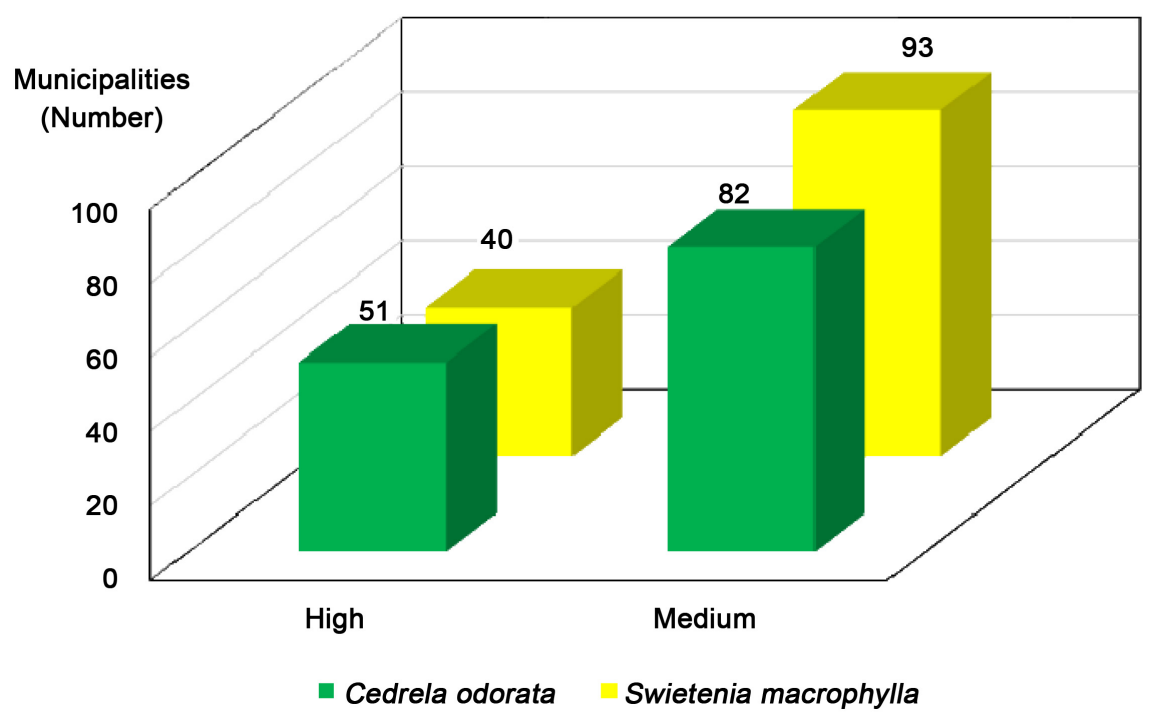

Figure 3. Number of municipalities with high and medium potential areas for Cedrela odorata L and Swietenia macrophylla King, in the state of Chiapas.

In Figure 4 the distribution of all high and medium potential areas, through the state, are being shown.

The outstanding municipalities with high potential areas in the North are: Catazajá, Palenque and La Libertad. From west to east, the outstanding ones are: Ocozocoautla de Espinosa, Tecpatán, Jiquipilas, Cintalapa, Hhuitiupan, Simojovel, Pantelhó, Chenalhó, Chalchiuitán and San Andrés Duraznal; whilst in the south part are: Ocosingo, Maravilla Tenejapa, Las Margaritas, Amatenango de la Frontera, La Concordia, Villa Corzo, Angel Albino Corzo, Chicomuselo, Tonalá, Pijijiapan and Mapstepec.

The Medium Potential areas were located in most of the geography of the state, standing out municipalities such as: Jiquipilas, Cintalapa, Las Margaritas, Amatenango de la Frontera, La Concordia, Villa Corzo, Chicomuselo, Villaflores, Motozintla, Mazapa de Madero, La Grendeza, Bejucal de Ocampo, Bella Vista, Frontera Comalapa, La Trinitaria, Chiapilla, San Lucas, Nicolas Ruíz, Totolapa, among others with smaller surface area.

Chiapas has adequate conditions for Cedar forest plantations in most of the State. Its climate is warm-humid with rainfall variations [21]; the annual average pluvial precipitation is $3087 \mathrm{~mm}$. The temperature reaches a lowest $9.5^{\circ} \mathrm{C}$ and during the summer it ranges from $34^{\circ} \mathrm{C}$ to $36^{\circ} \mathrm{C}$. The land is very rugged, mountainous, and heights ranging from sea level to four thousand five hundred meters above sea level [22].

\subsection{Distribution of Potential Zones for Mahogany}

Mahogany is the most important timber species in the country's forest industry [17] [23] [24] [25] [26] and it is among the group of precious tropical species highly used in Mexico [19]. Regardless of the large number of productive municipalities, as in the case of Cedar, just the most outstanding ones are mentioned. 
Those with High Potential areas are: Ocozocoautla de Espinosa, Palenque, Huitiupán, Simojovel and Sabanilla; however, the largest areas were classified as Medium Potential ones, all related to the complex relief of the state and scattered as shown in Figure 5.

Chiapas has $71.03 \%$ of its topography ranging from 0 to 1000 meters above sea level and confined the largest Medium Potential areas mainly located in the municipalities of Mapstepec, Pijijiapán, Tonalá, Catazaja, Salto de Agua, Palenque, Cintalapa, Jiquipilas, Villaflores, Villa Corzo and La Concordia.

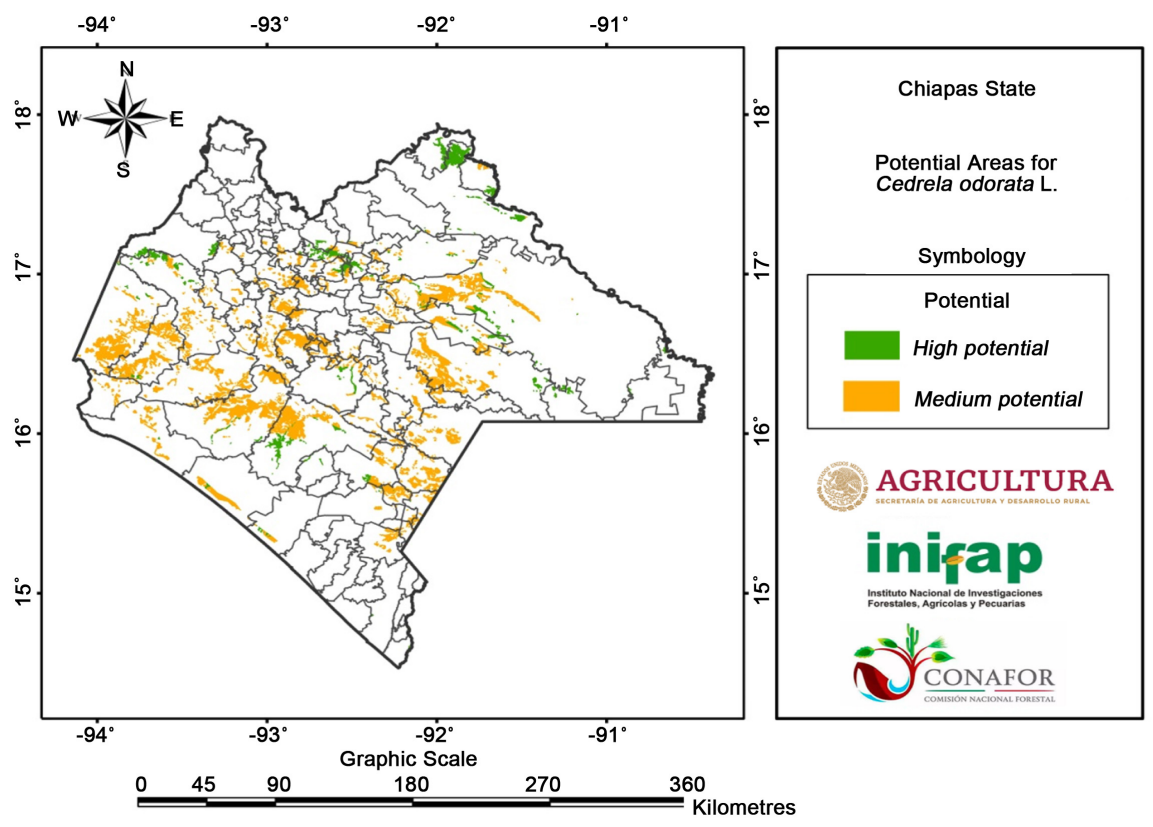

Figure 4. Distribution of potential zones for Cedrela odorata L.

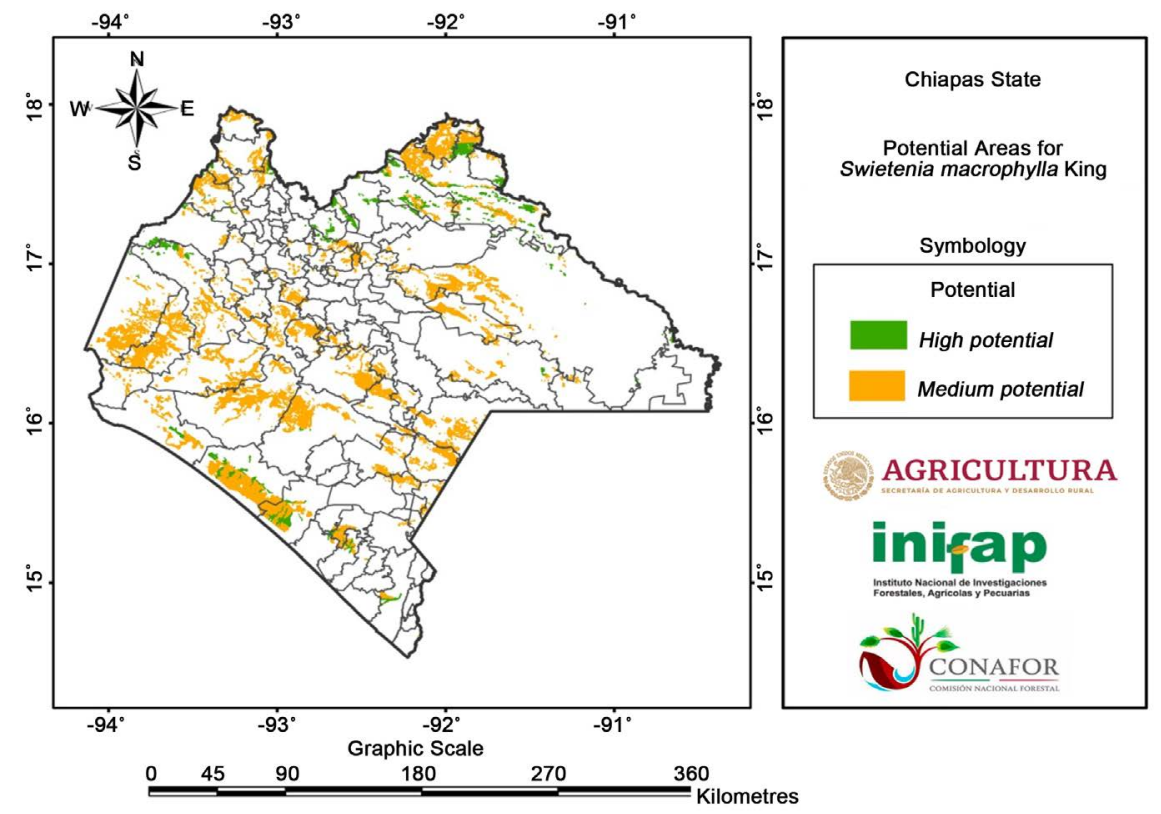

Figure 5. Distribution of potential zones for Swietenia macrophylla King. 


\section{Conclusion}

The results indicate that Chiapas has suitable agroecological areas, under rainfed conditions, to produce Cedar and Mahogany. There were found 428,465 hectares of Medium Potential and 81,116 hectares of High Potential suitable for cedar cultivation whilst for Mahogany were 91,939 hectares of High Potential and 629,000 hectares of Medium Potential. The surface found in this work far exceeds the current one reported and is distributed in 51 and 82 municipalities with high and medium productive potential respectively for Cedar and 40 and 93, in the same order, for Mahogany.

\section{Acknowledgements}

We thank the National Council of Science and Technology (CONACYT) and the National Forestry Commission (CONAFOR) from Mexico for financing this work as part of the project named: Network for Monitoring the Impacts of Silvocultural Practices in Commercial Forest Plantations for the States of Veracruz, Campeche, Tabasco and Chiapas, Mexico.

\section{Conflicts of Interest}

The authors declare no conflicts of interest regarding the publication of this paper.

\section{References}

[1] Patiño, V. (1997) Genetic Resources of Swietenia and Cedrela in the Neotropics: A Proposal for Coordinated Actions. FAO, Rome, $58 \mathrm{p}$. http://www.fao.org/3/ad111s/AD111S00.htm

[2] André, T., Lemes, M.R., Grogan, J. and Gribel, R. (2008) Post-Logging Loss of Genetic Diversity in a Mahogany (Swietenia macrophylla King, Meliaceae) Population in Brazilian Amazonia. Forest Ecology and Management, 255, 340-345.

https://www.fs.usda.gov/treesearch/pubs/29953 https://doi.org/10.1016/j.foreco.2007.09.055

[3] Bauer, G.P. and Francis, J.K. (1998) Swietenia macrophylla King, Caboa Hondureña. Meliaceae. Mahogany Family. 492-498.

https://www.srs.fs.usda.gov/pubs/30214/

[4] Arnáez, E. and Flores, E. (1988) Characteristics of the Wood of Cedrela odorata L. (Bitter Cedar, Meliaceae) in Costa Rica. Journal of Tropical Biology, 36, 67-73. https://revistas.ucr.ac.cr/index.php/rbt/article/view/23635

[5] Morales-Ortíz, E. and Herrera-Tuz, L. (2009) Cedar (Cedrela odorata L.) Protocol for its Collection, Post-Harvest Process and Storage. National Forestry Commission, Mérida.

[6] Cintron, B.B. (1990) Cedrela odorata L. Cedro, Spanish Cedar. In: Burns, B.R. and Honkala, B.H., Eds., Silvics of North America: 2. Hardwoods. Agriculture Handbook 654, Department of Agriculture, Forest Service, Washington DC, 128-134.

[7] Ruiz-Jiménez, C.A., De los Santos-Posadas, H.M., Parraguirre-Lezama, J.F. and Saavedra-Millán, F.D. (2018) Evaluation of the Categoring Extinction Risk of Red Cedar (Cedrela odorata) in Mexico. Mexican Journal of Biodiversity, 89, 938-949. 
https://doi.org/10.22201/ib.20078706e.2018.3.2192

[8] CONAFOR. National Forestry Commission (2012) Commercial Forest Plantation Development Program, 15 Years after Its Creation/Aurelio M. Fierros González, Compiler and Technical Editor. First Edition. Zapopan, Jalisco, Mexico. 196 p.

[9] Ramírez-Jaramillo, G., Lozano-Contreras, M.G. and Díaz-Maldonado, E. (2017) Potential Areas for Mahogany (Swietenia macrophylla, King.) Establishment in the State of Yucatán. Journal of the Graduate and Research Center, Technological Institute of Merida. 32, 107-113.

http://www.revistadelcentrodegraduados.com/p/blog-page_24.html

[10] Espinosa-Paz, N., López-Luna, A., Espinosa-Paz, H. Cadena-Iñiguez, P. and Vidal-López, C. (2015) Agroecological Potential Areas for Castor (Ricinus communis L.) Cultivation in the State of Chiapas. Technical Brochure $\mathrm{N}^{\circ} 22$. National Institute of Forestry, Agricultural and Livestock Research. South Pacific Regional Research Center. Chiapas Center Experimental Field, Ocozocoautla de Espinosa, Chiapas, Mexico. 15 p.

https://www.academia.edu/15551233/\%C3\%81REAS_CON_POTENCIAL_AGROE COL\%C3\%93GICO_PARA_EL_CULTIVO_DE_HIGUERILLA_Ricinus_communi s_L_EN_EL_ESTADO_DE_CHIAPAS

[11] National Institute of Statistics, Geography and Informatics (INEGI) (2009) Serie I. Edaphological Thematic Charts Scale 1:50,000. Chiapas, Mexico.

[12] Benacchio, S.S. (1982) Some Agroecological Requirements for 58 Crop Species with Production Potential in the American Tropics. FONAIAP-National Agricultural Research Center, Ministry of Agriculture, Maracay.

[13] Doorenbos, J. and Kassam, A.H. (1979) Effects of Water on Crop Yields. FAO Study: Irrigation and Drainage Paper No. 33, Rome.

[14] Food and Agriculture Organization of the United Nations (FAO) (1993) Ecocrop, Ecological Requirements of Plant Species Database. FAO, Rome.

[15] García, E. (1988) Changes to the Köppen Climate Classification System (To Be Adapted to the Mexican Republic Conditions). Offset Larios, UNAM, Mexico City.

[16] ESRI (1996) ArcView GIS. The Geographic Information System for Everyone.

[17] Pennington, T.D. and Sarukhán, J. (2005) Tropical Trees of Mexico: Manual for the Identification of the Main Species. National Autonomous University of Mexico/Fund for Economic Culture, Mexico, 56-65.

[18] Vázquez-Yanes, C., Batis-Muñoz, A.I., Alcocer-Silva, M.I., Gual-Díaz, M. and Sánchez-Dirzo, C. (1999) Trees and Shrubs Potentially Valuable for Ecological Restoration and Reforestation. Technical Report of Project J084. CONABIO/Institute of Ecology, UNAM, México, D.F.

http://www.conabio.gob.mx/conocimiento/info_especies/arboles/doctos/37-melia5 m.pdf

[19] Wegier, A., Barba-Escoto, L., García-Campusano, F., Pérez Santa Cruz, J. and Flores García, A. (2013) In Vitro Method to Establish Mahogany (Swietenia macrophylla King) from Vegetative Explants. Technical Manual No. 10. CENID-COMEF, INIFAP, Mexico DF, $84 \mathrm{p}$.

https://www.researchgate.net/profile/Andres-Flores-21/publication/325578830_Met odo_para_el_establecimiento_in_vitro_de_caoba_swietenia_macrophylla_king_a_par tir_de_explantes_vegetativos/links/5b16c892a6fdcc6d3e04cf84/Metodo-para-el-esta blecimien-

to-in-vitro-de-caoba-swietenia-macrophylla-king-a-partir-de-explantes-vegetativos. pdf 
[20] CONAFOR, National Forestry Commission (2020) The Mexican Forest Sector in Numbers. (2019) Forests for Social and Climate Well-Being. First Edition. Zapopan, Jalisco, Mexico. 96 p.

[21] Reyes-Reyes, J. and López-Upton, J. (2003) Growth of the Pink Cedar (Acrocarpus fraxinifolius Wight. \& Arn.) at Different Altitudes in Coffee Farms of Soconusco, Chiapas. Chapingo Magazine. Forest and Environmental Sciences Series, 9, 137-142. https://www.redalyc.org/pdf/629/62913142005.pdf

[22] Montoya, G., Soto, L., De Jong, B., Nelson, K., Farias, P., Yakactic, P., Taylor, J.H. and Tipper, R. (1995) Sustainable Forest Development: Carbon Capture in the Tzeltal and Tojolabal Zones of the State of Chiapas. National Institute of Ecology, Workbooks 4, México, D.F.

https://www.researchgate.net/profile/Bernardus_Jong/publication/242232842_Desarrol lo_forestal_sustentable_Captura_de_carbono_en_las_zonas_tzeltal_y_tojolabal_del _estado_de_Chiapas/links/00b4953baacee8965a000000.pdf

[23] Semarnat (Ministry of the Environment and Natural Resources) (2010) Statistical Yearbook of Forest Production 2010. Semarnat, Mexico D.F.

[24] Semarnat (Ministry of the Environment and Natural Resources) (2011) Statistical Yearbook of Forest Production 2011. Semarnat, Mexico City.

[25] Semarnat (Ministry of the Environment and Natural Resources) (2012) Statistical Yearbook of Forest Production 2012. Semarnat, Mexico City.

[26] Semarnat (Ministry of the Environment and Natural Resources) (2013) Statistical Yearbook of Forest Production 2013. Semarnat, Mexico City. 